AUthoR(S): n. ... Glasgow, M. S. Moore, G. L. Morgan, N. S. P. King, K. R. Alrick, H. L. Shepard, J. R. Streetman, G. M. Hale, J. H. Norman, L. R. Fawcett, and C. D. Bowman

J. A. Har"=y, N. W. H111, and R. R. Spencer

Submitted to: Int'1 Conference on Nuclear Data for Bastc and Applied Science Santa Fe, New Mextco May 14, 1.985

\title{
DISCLAIMER
}

This report was prepared as an account of work aponsored by an agency of the United Stated Government. Noither the Unitoc States Government nor any agency thereof, nor any of their employees, makes any warranly. express or implied, Jr assumes any legal liability or responability for the accuracy, completeness, or usefulness of any information, apparatus. product, or process dieclosed, or represents that its use would not infringe privutely owned rights. Reference herein to any spectfle commorcial product, process, or service by trade name, trademark, manufacturer, or otherwise does not necessarily constituto or imply its endorsement, recommondation, or favoring by the United Stalea Government or any bgency thereof. The viewa and oplntons of authors expreaced herein do not necensarily stute or ieflect those of the Uniter! Stuten Government or any agency thereol. 
TUE LOS ALAMOS NATIONAL LABORATORY NEUTRON-NEUTRON SCATTERING PROI..AM

DALE W. GLASCOW, MICHAEL S. MGORE, GEORGE L. MORGAN, NICHOLAS S. P. KING, KEITH R. ALRICK, MARLAN L. SHEPARD, J. RGBERT STREETMAN, GERALD M. HALE, JAY H. NORMAN, L. RAY FAWCETT, AND CHARLES D. BOWMAN

LOS ALAMOS NATIONAL LABORATORY, LUS ALAMOS, NEW MEXICO, USA AND

JACK A. HARVLY, NAT W. HILL, AND POBE?T R. SPENCER

OAK RIDGE NATIONAL LABORATORY, OAK RIDGE, TENNESSEE, IISA

\begin{abstract}
ABSTRAC' $A$ theoretical and experimenta] program is underway to determine the feasibility of a reasurement of the neutronneutron scattering cross section of 10-12\% uncertainty using small-angle, low center-of-mass energy, colliding nzutron beans derived from a fuslon-fission nuclear source. The neutron-neutron scattering length would be infeirnd from the measured cross sections. The gencial concepi of the experiments and progress are discussed.
\end{abstract}

\title{
IN'ROIDUC'IION
}

The neutron-ncutron scattering $1 \mathrm{cngth}$, ann, is a quantity of fundamental. Lmportance in nucjear and particle physics that still eludes a direct meinsurement. In potental language, she scaiterting length reflects the cumblattve effect of a putential over tise entire range of tateractlon. For nus lecin-nucleon scatering, the

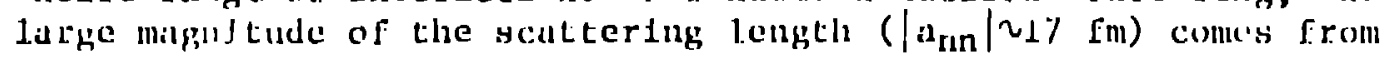
an almost-bound state in the spln-\%ero s-wave Lnteratefon and 3-4\% chinges tin $a_{n n}$ result from few-tenths \% chillges in the potential parameters. Therefore, the scal aring length 13 quice sensltedve to amall components of tho inter..ction among nucleons, such at; Couloml and three-body forces. As a resuit of lts high sensltivfty to the potential, the scitterering Length is a dlrect medsure of the chinge syumetey of forees between nucleons. Recent speculations

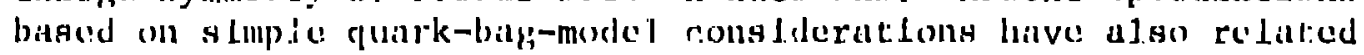

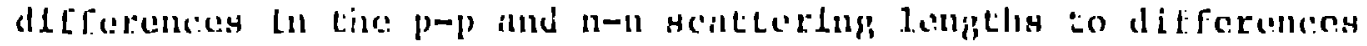

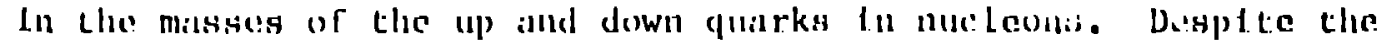

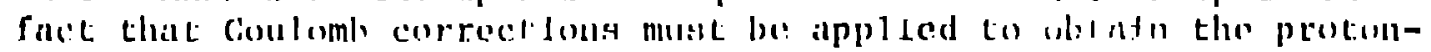

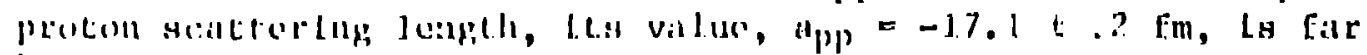

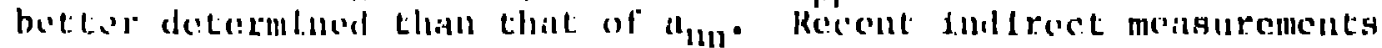

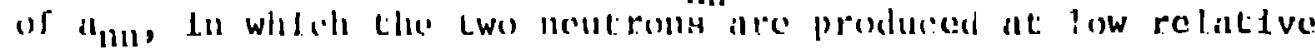

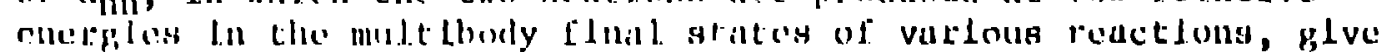




\section{GLASGOW, et al.}

values that disagree by four standard deviations, and lie on elther side of $a_{p p}$, giving ro clear indication of charge symmetry breaking in the nucleon-nucleon force. Theoretically, $a_{n n}$ is expected to exceed $a_{p p}$ by about 1 fin due to charge symetry breaking. The situation is summarized in Figure 1, which is taken from the work of Gabloud, who performed the latest ${ }^{2}$ II (I!; $\gamma$ ) nn measurements. ${ }^{1}$ The dashed horizontal line is a "world average" (-16.6 + $0.6 \mathrm{fm})$ of the kinemettally complete experiments, and the last point $(-18.6 \pm$ $0.45 \mathrm{fm}$ ) is Gabioud's value

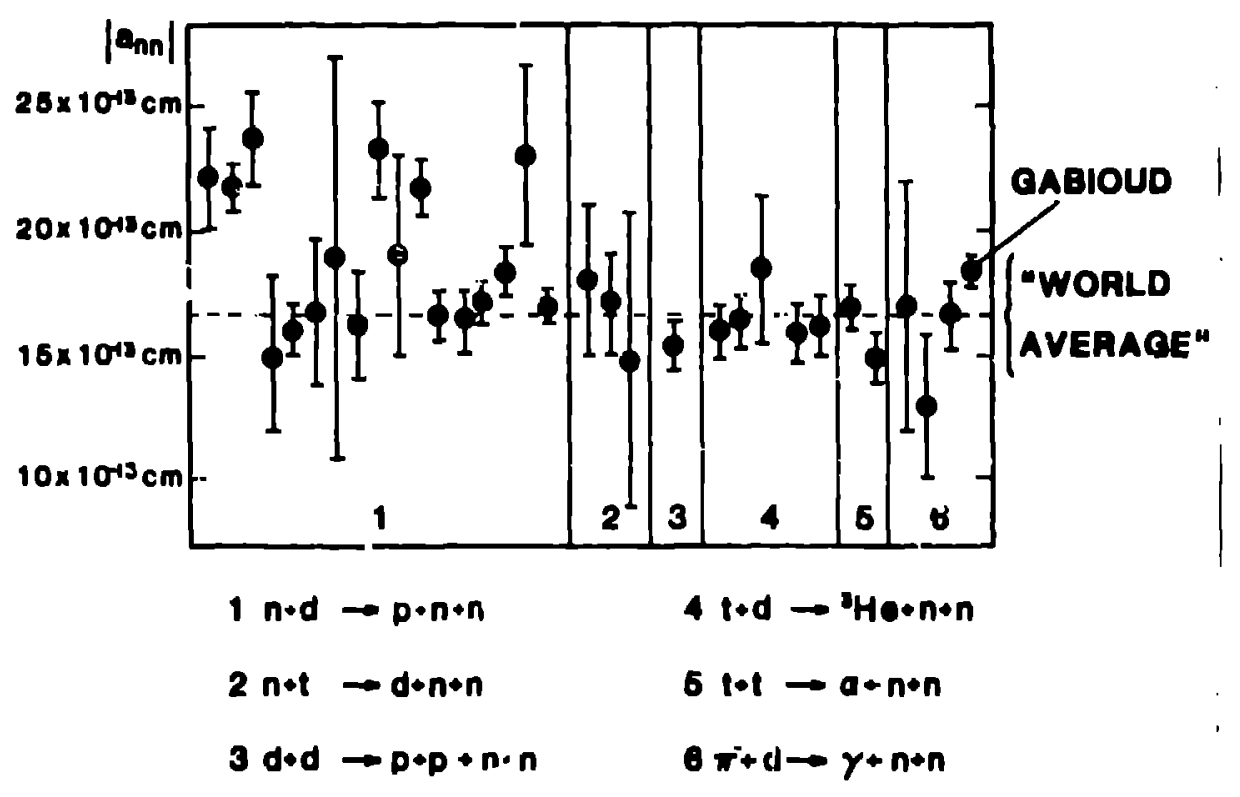

Figure 1. Distribution of n-n gantecting lengths. 'they' run chronologleidly loft to right.

There are two conflicting theoritcal views of the finferred an The extraction of a re! fable $e_{n !} f-o m$ the multibuly final state daca inust ut1llze full-blown, thrca-body faddeev seatecring theory.2 On the other hiand, some belleve the exiraction of $\mathrm{i}_{\mathrm{m}}$ [rom

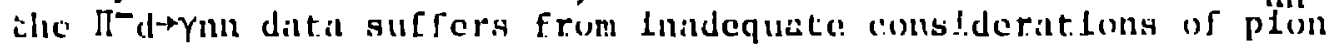
distortion, meson-exchange currents and lack of constitency of galuge Luvariance. 3 cleirly il drect measurement of an using collidlug neutron beams cfrcunivente all of these problems.

Dlekenson and Bowinan ${ }^{4}$ dlscussed selicmat liallly an expertment

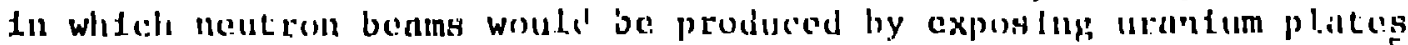

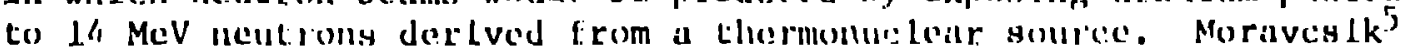
reported il computer study showhe the songletvicy of a the the potental parameters. Our computer studles Lidlcate thill ! $0 \%$

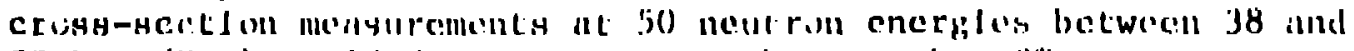
$22 \mathrm{keV}\left(\mathrm{l}_{\mathrm{cm}}\right)$ world delolomline and to beteer than $3 \%$. 
THE LOS ALAMOS NATIONAL LABORATORY NEUT-NEUT SCATTERING PROGRAM

\section{N-N SCATTERING EXPERIMENT}

The general concept of the experiment 1s shown 1: Figure 2. Neutrons from the source will transport through two heavily shlelded, collimated, evacuated, Incersecting lines-of-sight (LOS) to a collision volume in an evacuated tank. For simultaneous beams, collision kinematics dictate that all $n-n$ scattered neutrons will be confined within a forward right circular cone whose surface is generated by rotating the LOS's about the axis of symmetry. Those neutrons scattered along the edge of the cone w1ll be monoenergetic. by placing pairs of identfcal detectorg, one fust inside the cone surface and one just outside, the inside detector signal current will consist of nearly monoenergetic scattered neutron foreground plus background and the outside detector signal. currant will be background only. The uncollided neutrons are transported through two LOS's to two time-of-elight, recoll-proton spectrometers which are used to determine the respective differential velocity spertra $N\left(\nu_{i}\right)$ at the collision volume. These neutrons w1ll be transported further to a $\mathrm{CH}_{2}$ scatterer in one LOS and a C scattered in the other LOS in good geometry. The attenuated neutron $f 1 u x$ in each LOS $1 \mathrm{~s}$ then measured and the $n-p$ cross section is inferred. Thts provides a check on the spectrumeter experiments. Signal currents Erom the $n-n$ scatiered neutrons and background neutrons are generated in sclittilator-photomultiplier neutron detectors positioned as described carlier. The scattering system is laser aligned before source zero tinc. The neutron beam proflle at the scattering volume is determined via an imaging experiment. The entire scatering experiment is positioned inside of an extremely rigid pressuriaed tank $2.4 \mathrm{~m}$ diameter by $36 \mathrm{~m}$ long. This tank $1 \mathrm{n}$ turn sits on an I-heam structure. Whe n-n scntering cross section is extracted from a scatcering Integral and the $a_{n n}$ from the affective range approximation.

This small-angle $\left(3.8^{\circ}\right)$, coll1ding neution beam experiment has four pardmount features: (1) 'lhe entire pulse of $n-n$ evinte is throw shilply forward into a vory narrow kinematic cone with high concentrution of $n-n$ ruents neir the edge of the cone, (2) the $n-n$ detector 3 f.guld to lsotrople background varlea as the ratio 2/(1$\cos (x)=3600 / 1$, (3) CM col.1Lston energles of $38-4.4 \mathrm{keV}$ are produced for approaching noutron cuergles, In the laboratory aystem, of 14-2 MeV. The low (M collis lon energica guarantees S-wave scatterlug whleh s Lmplefieg the extriction of $a_{n n}$, (4) 'lhe $n-n$ Hcintering takies place at low cil energles whlle the detection of: the n-n scatcerlag cventes takes place at hlgh laboratory energles.

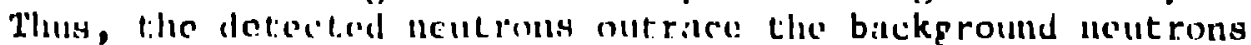
prodused mois the scittorling volume.

\section{EXPLIRIMILN'I S'INITSS}

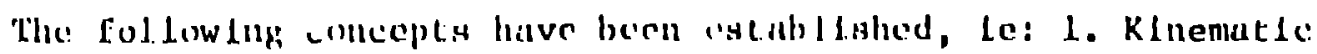




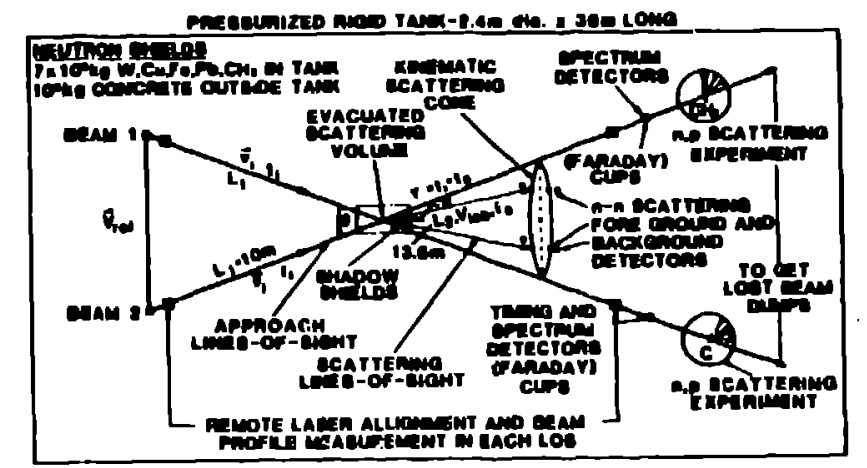

F1gure 2. N-N Scattering geometry

equations for small angle, colliding neutron beams produced by simultaneous (1-2 ns) and nonsimultaneous (4-8 ns) beams; 2 . Calculation of the scattering volume produced by colliding neutron beams emanating from a poirt source; 3. Monte Carlo calculations of the diffuse-boundary, scattering volume produced by colliding neutron beams emanating from a linite size source with neutron penetration of the collimation systems; 4. N_N Interaction rates, detector currents and locations, time and energy dispersion, and neutrons/energy resolution width, for a point and finite size source, scattering volume and detectors; 5. Unique current: signatures fron the $n-n$ scatterling foreground and background detectors; 6 . Uncertainties $1 \mathrm{n}$ measuring $10-12 \%$ n-n scattering cross sections; 7. Many successful tests of the ToF recol1-procon spectrometers, and overall. simultaneous operdtion of hundreds of wide-band oscllloscopes and computer-controlled, digital data recording systems; 8. Three-dimensional deslgn of the entire geometrical oysten using color graphics computer-alded design; 9. Monte Carlo sinulation of rulfation transport through the LOSs, shlelding, scacterlng tank, shadow shlelds, re-emergent neutron cavities and beam dumps with the production of foreground signils from the LOSs and backgrounds from the shlelding, ete.

\section{EXPLERIMENT SCHEDULLE}

1. Test of source and simultanelty - 1986.

2. prouf of prlaciple test - 1987.

3. MaLn $n-n$ scattoring expertment - 1988 .

\section{REFERIENCES}

1. H. Gabloud, et a1, Plyys. Lett. 103H, 9 (1981).

2. K. Thayler, ot al, prtvate Communleatlon, March (1984).

3. Z. J. Can and W. Y. P. Ilwillsh, Phys, Rev. C $29(1984)$.

4. W. (.. 1)1ckenson and (. 1). Bowman U(T) 70376 (1967).

5. M. I. Moraveslk, plyys. Rev. 136, 13624 (1964). 